\title{
A DESTERRITORIALIZAÇÃO DOS SABERES E FAZERES ANTROPOLÓGICOS E O DESENTENDIMENTO NO CORPO DE VERDADE DA LETRA
}

\author{
Ana Luiza Carvalho da Rocha \\ Viviane Vedana \\ Priscila Farfan Barroso \\ Rafael Lopo
}

O tema da desterritorialização/descolonização dos saberes e fazeres antropológicos pela via da crítica ao estatuto da escrita na construção da representação etnográfica e dos processos de mundialização, vem engendrando ao longo das ultimas décadas o debate acerca da ética do antropólogo diante da diversidade cultural. Instrumento de poder ou via real do saber adotamos com J. Rancière o ponto de vista segundo o qual o ato da escrita é ato de partilha do sensível (modos do fazer, modos do ser e do dizer) para refletir sobre as condições que cercam a etnografia como texto. Com isto a intenção é recolocar alguns dos dilemas que vive a Antropologia em termos das possibilidades da escrita etnográfica configurar-se como uma partilha do sensível entre os próprios antropólogos.

Segundo postula J. Rancière, mais do que a partilha de um saber objetivo ancorado no estatuto de uma linguagem de "verdade" que emana da letra, órfã, a partilha do sensível é lugar desde onde o inteligível se apresenta, não mais o inteligível como o entendimento recortando os objetos, mas como parte do comum de sentido construído por uma comunidade. Interessa-nos neste artigo pensar o comum de sentido que os próprios antropólogos atribuem ao lugar da escrita para a produção de seus saberes e fazeres. Em especial, ao se colocar as diferenças da etnografia fora do trabalho de campo e no interior do corpo da letra, descobrimos que a escrita antropológica é coisa política porque recoloca o diálogo entre civilizações nos termos das relações entre, por um lado, um conjunto comum partilhado de saberes e, por outro, a sua divisão em partes exclusivas (saberes tradicionais/saberes científicos, o que pertence ao "nativo"/o que pertence ao etnógrafo).

Esta coisa política da escrita etnográfica é apresentada também por Michel de Certeau (1995) quando o autor comentando a etno-grafia aponta algumas questões importantes que cercam as diferenças entre a escrita e a palavra viva do outro e que se revela concretamente tanto no in-audito e nas marcas do visível da vida vivida por ele em 
toda a sua plenitude (a palavra sem escrita ou a palavra possuída). Trata-se aí desta coisa política da palavra viva com a qual todo o antropólogo tem que dialogar, na qual tem que submergir e da qual tem que emergir para desde aí, através do corpo da letra, se iniciar no método etnográfico desde suas modalidades de práticas escriturísticas. Não se trata de nada absolutamente original o que estamos afirmando pois toda a literatura antropológica mais recente dos estudos de performance e, em particular da performance da fala, apontam para esta dimensão da palavra viva que por muito tempo foi tratada como um dejeto na produção textual do antropólogo.

Destas observações seguimos adiante! Segundo J. Rancière (1995) a escrita opera uma re-divisão entre a ordem do discurso e a das condições de enunciação da palavra viva, e por isto mesmo carrega consigo a dupla crítica, ser ao mesmo tempo muda e falante demais. Muda porque, como até mesmo reconhece o antropólogo visual Macdougall (1998), não há ninguém para dar voz presente ao corpo da letra depositado sobre a folha de um livro, e, portanto, para the atribuir verdade. Por outro lado, é falante porque se oferece como ato de palavra a todo aquele que a ela tem acesso.

Lembrando-nos a polêmica entre as nossas sociedades e aquelas de tradição oral, para este autor a escrita na condição de letra morta rola solta para todos os lados sem saber seu destino, a quem deve ou não falar. Qualquer um pode se apoderar dela ou dar ao seu corpo uma vida que não é mais "a dela", determinando desde este momento, uma outra partilha do sensível. A escrita tem, portanto a capacidade perturbadora de transformar a palavra viva enunciada, mesmo pelos povos que dela não partilham, em letra morta, a qual, mais tarde, deve retornar à vida pela mão daquele que dela se apoderar. Contrariando as afirmações em voga do caráter elitista do corpo da letra, segundo ainda este autor (Rancière, 1995) a perturbação teórica da escrita tem um nome político: chama-se democracia.

Para se ter mais claro o que acabamos de enunciar vamos nos deter um pouco mais sobre seu ponto de vista sobre o ser da coisa literária e a sua opacidade (Ranciére, 1995: 25), oriunda da transformação, por deslizamento histórico (a passagem de um saber para uma arte) da palavra literatura num sacerdócio ou numa nova nobreza. Um processo que remonta a época em que a literatura não era a arte dos escritores, mas sim o saber dos letrados e as suas formas de apreciar as belas-letras. Será somente no século XIX que o 
termo literatura irá designar aquele que escreve, se confundindo com o ensino das formas de se apreciar as belas-letras para, finalmente, fundar sua historicidade desde os primórdios das eras, dos textos sagrados e saberes retóricos, aos romances modernos, passando pelos grandes gêneros poéticos - trágico, épico, lírico.

Segundo J. Rancière as artes das línguas guardam relações estreitas com os saberes tradicionais, e o próprio o termo literário em suas origens não se reduz à literatura. A literatura (uma perturbação entre os modos e os gêneros do discurso) na procura da afirmação de seu campo de sentido desvaneceu o sentido comum atribuído anteriormente aos saberes tradicionais, tendo com isto contribuído para a sua supressão. O romance (que se desliga da subordinação do elocutio), como experiência e prática autônomas da linguagem, traz um exemplo significativo do que afirma o autor. O termo literatura para o autor contempla uma guerra da escrita ao desmanchar a estabilidades organizadas da ordem dos discursos e da ordem dos estados (Ranciére, 1995: 26).

A influência do romance ${ }^{1}$ na escrita etnográfica quer queiramos ou não, alinhandonos com o pensamento do autor, instauraria o tema do próprio e do impróprio do corpo da letra já no coração da produção textual da Antropologia. Uma das razões pela qual a etnografia não se resumiria, assim, reafirmando as palavras de C. Geertz, a um fenômeno que se resolve apenas no interior do encontro etnográfico e do caráter dialógico das trocas que ocorrem entre o outro e o antropólogo em processo de trabalho de campo. O texto etnográfico e o espaço livresco, através da forma literária que adota o registro de suas relações com o outro, apontam, de forma mais vigorosa ainda, para a necessária reflexão do antropólogo em todo o seu esforço por restaurar, na palavra escrita, as posições diferentes desde onde a palavra viva do outro foi capturada/exilada. A escrita, em seu sentido mais amplo possível, perturba a ordem do discurso antropológico sobre o outro e a pretensão deste conhecimento devolver a este outro a sua assinatura no mundo.

Neste sentido, o trajeto da letra na produção textual dos antropólogos abarca questões que estão além daquelas referidas as suas propriedades internas, pois,

\footnotetext{
${ }^{1}$ Vale a pensar o exercício de se pensar o tema da "antropologia do ponto de vista do outro" de que fala C. GEERTZ desde os comentários que J. RANCIÉRE (Políticas da Escrita, 1995: 39) promove sobre o lugar da figura do autor (do "eu estive lá") e a conceituação da objetividade do romance épico. Segundo o autor em Platão, a figura de Homero é a de um fraudador, que se esconde no poema; em Aristóteles, Homero sabe desaparecer no poema para melhor organizar o engano e em Hegel, o "esconder-se no poema" é a efetuação da verdade própria ao poema, expressão da objetividade épica, uma propriedade do poema.
} 
desencarnada da vida vivida, ela pode tomar qualquer corpo e ser interpretada desde um comum de sentido dado no interior de uma comunidade lingüística (aqui dependendo a quem a obra se dirige $)^{2}$. A partilha ou não de um sentido comum para o corpo da letra nas regras das asserções do pensamento antropológico e nas suas modalidades de construir conhecimento sobre o outro e a sua cultura é que remete a perturbação literária para o interior da representação etnográfica. Seguindo-se a argumentação de J. Ranciére (1995: 41) a perturbação do literário na escrita se desdobra no intervalo que separa a fábula da letra abandonada à procura de um pai para o seu discurso da fábula do corpo da verdade, do logos, que a letra emancipada, tornou carne sensível do mundo.

Agregando-se este ponto de vista ao de Michel de Certeau, podemos finalmente recolocar em outros termos, o de que o literário na produção do conhecimento antropológico (e no mundo dos livros onde a sua palavra circula) nos leva a refletir sobre a dramaturgia das relações entre o estatuto da letra e o estatuto de enunciação e de seus poderes na produção da reflexão antropológica, através da qual se aprofunda a aventura da letra na produção textual da etnografia. Um processo que J. Rancière (1995: 77) denomina a "teologia" do corpo da verdade da escrita.

\section{Anunciando a escrita como partilha do sensível, o lugar do mal-entendido e/ou desconhecido e do desentendimento}

Voltamos novamente a Michel de Certeau (1995:82) para recolocar o que estamos aqui procurando dimensionar como sendo a aventura da produção da etnografia como texto. Ou seja, o lugar do ato de escrita para a ancestralidade da construção do conhecimento antropológico, apoiada no desaparecido cujo vestígio ela carrega, visando ao inexistente que ela promete sem dar, ela permanece o enigma da esfinge. Entre as ações que simboliza, ela mantém o espaço problemático de uma interrogação. Conforme o autor (M. de Certeau, 2002:217), a palavra é aqui o corpo que significa. A escrita é por isto arquivo, registro, repetição indefinida. Ela preserva e conserva contra a voz do outro transformandoa, isolando-a do seu dono, ainda que tente manter intacto o seu lugar de produção. Se a

\footnotetext{
${ }^{2}$ Cf. J. RANCIÈRE, Políticas da Escrita, SP. Ed. 34, 1995, no poema épico (livro da vida de um povo ou poema do povo) o discurso vivo leva a potência de seu pai, e o que filia um poema a um pai é a unidade imediata, de voz e de corpo, entre uma subjetividade singular e uma comunidade ética. O poeta é tanto filho quanto pai de seu discurso, algo que a civilização da escrita e seus modos de fazer, de dizer e de ser irão separar.
} 
oralidade pode ser confundida com o mundo natural, a escrita tem suas evidencias de que o mundo natural não lhe pertence; o seu universo é o dos livros e o seu lugar o mundo o literário.

Através das observações de Michel de Certeau (2002:219) podemos retraçar os emaranhados da hermenêutica do outro através da prática escriturística da etnografia e a presença do mal-entendido e/ou do desconhecido no seu interior assim como a presença do desentendimento, nos termos de J. Rancière aceitando, por outro lado, o corpo de verdade da letra como espaço importante para a construção do pensamento antropológico em cujos meandros férteis o conhecimento ali floresce.

Vamos então retraçar algumas destas operações da prática escriturística da etnografia e seus meandros. A primeira operação literária que o autor menciona da etno-grafia é o corte estrutural, o do mundo de "lá" e o mundo de "cá", já suficientemente explorado por C. Geertz na sua obra $O$ antropólogo como autor. Ou seja, o etnógrafo construindo um enquadre de "dessemelhanças" entre ele e o outro (um desvio com relação ao que se vê de $c a ́$ ), pensa o outro como fragmentos resultantes do estilhaço da sua própria cultura.

Este primeiro corte conduz a outro (segunda operação), mais sutil, que é fazer o outro retornar ao mesmo, partindo o etnógrafo da fratura entre os dois mundos, provocada por seu olhar e direcionada pela escrita, organizada no sentido de fazer para o leitor a passagem do lado de "lá" para o lado de "cá". Aquilo que era exterioridade no outro é reconhecido como portador de sua interioridade, entretanto, numa identidade colocada fora de si (no corpo da letra), do contexto da voz do outro, da sua palavra viva. Vai-se assim do outro ao mesmo e do mesmo ao outro, numa tentativa de captura do sentido do próprio de sua voz pelo corpo da letra, passando-o para a linguagem ocidental. O que neste momento é fantástico é a identificação por Michel de Certeau (2002:224) da herança da exegese cristã no computo desta hermenêutica do outro, herdada pelo texto etnográfico do Ocidente judeu-cristão (a tradição bíblica que remonta a antiguidade grega e latina) - retornando com este autor as estudos de M. Foucault (As palavras e as coisas), G. Durand (Science de l homme et Tradition) e J. Rancière (Políticas da Escrita). Não se trata de coincidência entre pontos de vista de autores, mas de nossa intenção precípua de demarcar os limites de uma possível investigação sobre o tema das filiações da fonte escrita na representação etnográfica. 
Na seqüência adentramos uma terceira operação, ainda mais sofisticada: privada de sua efetividade, a palavra viva tornada órfã (pela fuga dos locutores) adquire no corpo da letra progressivamente um estatuto de linguagem privada de "substância". Uma operação que prepara o espaço da palavra escrita como linguagem pura da racionalidade contra os enunciados enganosos da voz do outro (em razão de suas condições inconscientes). Este ponto nos remete quase que automaticamente no âmbito da quarta operação, a da prática escriturística propriamente dita, ou seja, da etno-grafia desde a exterioridade de sua produção textual como inteligibilidade do outro (que está alhures), lugar de produção de verdades uma vez que instaura uma posição de saber entre uma comunidade de letrados (em particular, a comunidade lingüística de pertença de todo o etnógrafo, a Antropologia).

Nesta última operação, diferente das anteriores, é que passamos finalmente dos problemas do mal-entendido e/ou do desconhecido na representação etnográfica do outro para o do desentendimento como espaço importante de reflexão sobre as possibilidades da etnografia como texto uma vez que "os casos de desentendimento são aqueles em que a disputa sobre o que se quer dizer e falar constitui a própria racionalidade da situação da palavra" (J. Rancière, 1996:12). Este aspecto pode ser associado ao que C. Geertz (2002:27) aponta sobre os dilemas de R. Firth não apenas da distância etnográfica que separa o outro e sua cultura do antropólogo e sua comunidade lingüística, mas principalmente ao regime da escrita onde a palavra do antropólogo disputa sua racionalidade no interior dos saberes letrados.

Ainda do ponto de vista do que estamos afirmando, M. Sahlins em sua obra Ilhas de História (2006) aborda, sob outra forma, o tema desentendimento que cerca a condição do corpo da letra na pratica da etno-grafia e nos permite re-situa-la desta vez no coração dos encontros do outro com a civilização do antropólogo e no contexto da ordem cultural mundial. Com o autor podemos refletir sobre as condições que cercam a escrita etnográfica quando esta se encontra submetida às tensões oriundas entre as ordens culturais diversas que reúnem o nativo e o antropólogo num confronto etnográfico e onde o que esta em jogo do que se quer dizer e falar do outro constitui a própria racionalidade da situação da palavra do etnógrafo. Apoiando-se em um dos personagens do livro Alice no país das maravilhas, o autor recoloca o velho novo tema do mundo pós-colonial. Isto é, o tema das perspectivas diferentes que reúnem o etnógrafo ao nativo e dos poderes diversos que ele detém para $a$ 
objetivação de suas interpretações, e vice-versa: a questão é saber quem será o senhor das palavras e dos seus sentidos. Ultrapassamos aqui o limiar das discussões clássicas do desconhecimento ou do mal-entendido da cultura do outro e mergulhamos vertiginosamente para as questões do desentendimento tal qual elaborado por J. Rancière no inicio deste artigo.

Para este autor (Sahlins, 2006:13), na perspectiva da etnohistória, diante do pensamento nativo a escrita antropológica não pode perder sua identidade uma vez que para conhecer o ponto de vista do nativo o etnógrafo não precisa renunciar a si mesmo nem ao seu lugar no tempo: é preciso outra cultura para conhecer outra cultura. Recorrendo a T. Todorov e a sua noção de exotopia, M. Sahlins (2001) opera com a externalidade do etnógrafo no arranjo geral de outros esquemas culturais. Não haveria para ele nenhuma possibilidade de se pensar uma antropologia do ponto de vista do nativo. Seriam o desprezo pelo outro e a missão civilizatória do europeu na teoria acadêmica uma das razões pela qual o etnógrafo se imagina atingindo a concepção nativa de cultura como se esta pairasse no ar, longe dos contatos prévios entre suas sociedades historicamente relacionadas.

\section{A escrita, o corpo da letra, a palavra vivia e o enquadre de "dessemelhanças"}

Este esforço em delimitar o corpo de verdade da letra tem frequentemente conduzido os antropólogos a situar o problema do mal-entendido e/ou do desconhecimento no âmbito das modalidades de gêneros narrativos adotados pelos etnógrafos em sua produção textual. Entretanto, segundo o que apontamos a filiação da palavra seja do antropólogo, seja do nativo, tenciona-se com o corpo da letra ao longo da cultura ocidental como produtora de "verdade' pois ela tem por característica, em seu trajeto antropológico, apagar a semelhança que permite atribuir um discurso ao seu pai (Ranciére, 1995: 28).

Para aqueles que desejam eliminar a perturbação que promove a etnografia como texto para o pensamento antropológico vale lembrar o alerta nos dá J. Rancière: há um risco ou perigo de atribuir ao corpo da letra um corpo de verdade: o de livrar-se da perturbação da letra órfã na busca insana de seu pai (o pai do discurso), o que originaria o estado prosaico do discurso.

Neste ponto, o literário passaria a ser incorporado à literatura, referido a uma 
substancialidade ética e ao seu vasto campo de relações e onde despontam os temas nacionais, regionais e locais; um fenômeno que tende a contrapor-se violentamente contra as andanças da letra órfã. ${ }^{3} \mathrm{O}$ autor analisa em particular o caso do poema épico para comentar o corpo exemplar de verdade que ele carrega e suas heresias em contraste com a prosa do mundo: da letra sem corpo e do espírito errante que o afastam do acabamento racional da prosa.

Portanto, falar da etnografia como texto é tratar da inquietação que o corpo da letra promove para as praticas de trabalho de campo do antropólogo. A escrita etnográfica promoveria, assim, a perturbação do sentido no interior do pensamento antropológico que para pensar o outro precisa se confrontar com o rapto da palavra viva do outro pela palavra escrita e a ruptura do seu sentido original pelo no corpo da letra muda/tagarela.

Com J. Ranciére temos visto que é possível avançar na reflexão em torno da presença do literário não apenas na literatura para os avanços do trabalho de campo em Antropologia, e deste forma extensivamente até mesmo para s singularidade da produção do conhecimento antropológico. Obviamente o literário (desde onde se origina a representação etnográfica nos livros) aqui conceituado, conforme o autor, desde a questão do corpo da letra e da dramática da escrita. O que nos faz re-encontrar C. Geertz (2002b: 82), e seus comentários sobre os sentidos do trabalho da etnografia, ou pelo menos um deles, qual seja a de realmente proporcionar, como a arte e a história, narrativas e enredos para redirecionar nossa atenção (...) que nos tornem visíveis para nós mesmos, representando-nos e a todos os outros como jogados no meio de um mundo repleto de estranhezas irremovíveis, que não temos como evitar.

Esta para nós seria uma das razões mais legítimas que faz com que a etnografia possa ir além da experiência do trabalho de campo e adotar como expressão de si o pensamento da escrita. Ao contrário do que se pensa, a representação etnográfica estaria assim, desde a sua fonte escrita, nutrindo-se da perturbação do literário, da aventura da letra e da sua potência de fabulação diante do desafio de dar ao corpo da letra uma vida e honra, assim, a captura da voz outro.

\footnotetext{
${ }^{3}$ Uma posição que remete segundo J. RANCIÈRE a inquietação que o literário contempla na aventura da letra sem corpo. Um fenômeno que ocorre para o caso do livro da vida quando ele se transforma de um momento da vida objetiva do espírito (verbo encarnado, da tradição cristã) na presença viva do espírito corporificado por uma comunidade (expressão da alma de um povo).
} 
Diante do que estamos afirmando, a produção textual para o conhecimento antropológico contemplaria, portanto, uma dramaturgia, não podendo ser usada para apaziguar, portanto, algo que o próprio do corpo da letra já manifesta como disjunção primeira entre corpos e discursos, a palavra viva e a letra morta, mais tarde, órfã, muda e falante. C. Geertz (2002b) nos lembra a atenção necessária ao que a etnografia pode por ela mesma servir como matéria de distinção não só de discursos. Ao nós complementaríamos distinção também de corpos, nos termos de J. Rancière. Ao contrário, aceitando a perturbação do literário que a escrita antropológica contempla podemos jogar uma nova luz sobre a Antropologia (Geertz, 2001) no sentido de um pensamento antropológico que se pensa pensando a partilha do sentido entre as sociedades humanas e as divisões dos discursos e dos corpos.

Não por acaso retornamos ao argumento das diferenças entre mal-entendido e desconhecido e as questões do desentendimento (Rancière, 1996) como sendo uma das centrais a serem percorridas para o tema deste artigo uma vez que a escrita etnográfica, dada a perturbação do corpo da letra, da aventura do sentido que ela carrega, se encontra no olho do furacão da polêmica em torno da divisão de discursos que o estudo da diversidade cultural faz emergir no corpo de nossas modernas sociedades contemporâneas. Principalmente pela forma como, em suas entranhas, a palavra viva do outro (dentro das fronteiras de um "nós"4) se emancipa e se torna o corpo da verdade do logos de um discurso, o do antropólogo.

\section{A descolonização do saber e a fonte escrita do conhecimento antropológico}

Se imagens e palavras são lugares da memória para muitas das sociedades e culturas ditas de tradição oral, para as sociedades contemporâneas e a civilização da escrita muitas vezes elas se traduzem apenas como veículos de comunicação e consumo. Por um lado, no mundo pós-industrial, a cultura tem obtido um grau de autonomia cada vez maior, tornando-se importante componente técnico da estruturação das sociedades, obrigando antropólogos algumas vezes a competir com políticos ou até mesmo a converterem-se em seus aliados. Por outro lado, a controversa acerca da fonte escrita do conhecimento antropológico diante do tema da descolonização do saber antropológico tem engendrado o

\footnotetext{
${ }^{4}$ CF. C GEERTZ, Nova luz sobre a antropologia, RJ. Zahar Editores, 2002:77.
} 
debate em torno da ética e da estética contida na produção textual dos antropólogos no sentido desta contemplar a diversidade cultural, escapando à lógica de um discurso hegemônico fechado às diferenças culturais, numa luta contra o fim do humanismo que lhe deu origem.

Para o tema deste artigo, este panorama complexifica o debate em torno das possibilidades da etnografia como texto, principalmente diante do diálogo civilizacional que cada vez mais se impõe às fontes escritas do pensamento antropológico e a idéia de que a antropologia se afirmaria como descrição cientifica das constantes de uma cultura, a partir do encontro autentico com o outro. Diante da cena da crise da razão e da ciência, do relativismo pós-moderno que situa a "verdade" na dependência das múltiplas épistèmés, torna-se usual que os antropólogos tomem para si o desafio de que a sua produção textual , muitas vezes ao ser des-contruída em seus aspectos literários, lhe permita finalmente a travessia entre as duas margens do rio, por um lado, a dos saberes tradicionais orais (e até mesmo os escritos) e, por outro, a dos saberes científicos, modernos. O estatuto da representação etno-gráfica das fontes escritas (e evidentemente que não só elas) é, neste sentido, colocado em questão e até mesmo desafiado.

A problemática da inegalidade, da exclusão, da discriminação na tessitura das interações entre a sociedade do antropólogo e a do outro invadem a cena, colocam sob suspeita as fontes escritas do pensamento antropológico, criando desconfianças em torno do poder democrático do corpo da letra no interior e fora do espaço livresco. A produção textual dos antropólogos é pressionada a assumir um papel no processo de produção de justiça social no plano das identidades emergentes no mundo pós-colonial.

A mundialização do debate sobre democracia, a liberdade e a igualdade em termos da repartição de bens e riquezas no interior das sociedades humanas se alastra e atinge as questões da produção de sentido para o mundo e expõe a Antropologia.

A politização da escrita se desloca para outros campos como o das práticas museográficas, museológicas e arquivísticas que majoritariamente no Brasil nos últimos anos ainda tinham sido poupadas. Se aprofunda a discussão em torno do direito a "propriedade" dos antropólogos sobre os dados etnográficos e as informações obtidas de povos e culturas que não tem na escrita sua forma de transmissão de conhecimento.

Os antropólogos num processo de mundialização se tornaram experts das culturas, 
tradições e costumes de tais sociedades. $\mathrm{O}$ ato de ver, ouvir e escrever que antes eram suas ferramentas em campo passam a ser questionados em sua capacidade de interpretar as palavras e os atos de outras culturas e povos, não apenas de tradição oral, mas que não tem no corpo da letra um valor simbólico.

Os princípios de justiça aplicados ao domínio da produção de sentido através da fonte escrita e do espaço livresco se tornam uma questão interessante para a própria produção do conhecimento antropológico na forma como isto afeta as suas formas de expressão de pensamento na contemporaneidade.

Não há mais como o etnógrafo se relacionar ingenuamente com a fonte escrita de seu pensamento nem como forma de expressão de seu conhecimento. Tendo em vista a tradição oral ou o iletrismo de grande parte dos grupos humanos com os quais os antropólogos trabalham, esta polêmica da propriedade dos seus conhecimentos inicialmente atinge apenas uma parcela pequena de seus sujeitos de pesquisa (em sua maioria "nativos" convertidos em antropólogos). O que faz com que a controvérsia aqui apontada não vá muito além dos muros da comunidade lingüística dos antropólogos.

Entretanto, pela via da globalização, os efeitos das fontes escritas da representação do outro em outras mídias (televisão, web, etc.) passa a ser cada vez maior. A sedução frequiente do consumo da imagem do outro como espetáculo tem favorecido o intercâmbio dos antropólogos com outros profissionais que atuam nos veículos de comunicação (formadores de opinião pública). Ainda que sejam poucos os casos, e apesar das boas intenções em divulgar os direitos de grupos e/ou comunidades com as quais trabalham, o diálogo dos antropólogos com a sociedade do espetáculo e a sociedade de consumo está sempre repleto de tensões e de desconfiança.

Entre os seus pares, um antropólogo na mídia geralmente provoca um sentimento de insegurança e de desconfiança significando a representação etnográfica se desprender do espaço livresco, seu meio de expressão original, para atingir outros graus e dimensões interpretativas os quais o próprio antropólogo não tem nem o domínio, nem o controle. O mal-estar da presença de antropólogos em entrevistas a programa de televisão, em documentários, colunas de jornais, etc. embora aparentemente não aponte para a crise da representação da fonte escrita para as formas de produção de conhecimento em Antropologia está a ela vinculada. Quando tal situação ocorre sabemos que o "mal-estar" 
invade a cena dos congressos, simpósios e encontros nacionais e internacionais onde estão reunidos os antropólogos.

Portanto, enquanto alguns antropólogos buscam este encontro da Antropologia com outras mídias, como forma de construir formas mais legítimas de representação do outro e de devolução de sua palavra aprisionada, outros criticam o namoro entre saberes científicos e as mídias contemporâneas por ser uma fuga dos reais problemas que ocorrem no campo de produção de conhecimento de origem. No meio deles, é que se pode ver o movimento de alguns antropólogos para conciliar ambos os desafios sem, entretanto, cair nas armadilhas do anti-anti relativismo.

A afirmação da democracia da letra, entretanto, não é uma questão pela qual responde apenas o antropólogo. Ela se instaura além do campo dos saberes antropológicos uma vez que se produz e reproduz nas entranhas de sua própria sociedade. Através de campanhas de alfabetização em prol do acesso amplo dos segmentos sociais mais pobres dos modernos Estados às fontes escritas, das trocas estreitas das populações marginalizadas com as organizações não-governamentais, do contato de povos e culturas não-ocidentais com a indústria do turismo, além do seu contato cada vez mais intenso com os antropólogos de todas as formações, os antigos "nativos" iniciam sua caminhada rumo à apropriação de conceitos e idéias do campo do conhecimento antropológico. O que antes apenas circulava através de uma produção textual dirigida a especialistas agora o etnógrafo escuta pela boca do próprio "nativo".

Nos dias atuais, não só os antropólogos se tornam importantes mediadores culturais como inúmeros membros das ditas sociedades tradicionais (o "outro", o "nativo") assumem este papel, na contemporaneidade, disseminando entre suas próprias comunidades de pertença o tema da crise da representação, não apenas etnográfica.

Hoje nos ocupamos do tema da proteção ao meio ambiente tanto quanto falamos de proteção às culturas locais, aos complexos culturais que religam as tradições e aos costumes dos povos e aos territórios onde vivem. Os bens imateriais, e não apenas os bens materiais, que antes traduziam as fontes escritas dos relatos etnográficos não são apenas da alçada da comunidade lingüística formada pelos antropólogos; eles são de domínio e interesse direto das próprias comunidades de onde saíram. Cada vez mais as fontes escritas do conhecimento antropológico engajam uma nova audiência e integram outras reivindicações, 
para além do espaço livresco que era seu destino.

Isto significa que progressivamente o caminho da pesquisa antropológica com a fonte escrita de suas representações, com suas formações discursivas, com os teatros de suas linguagens, as figuras dos autores, leitores e escritores dos textos etnográficos deriva em dados e informações marcadas pela polêmica da ética no interior da sua produção de conhecimento.

Para a prática da investigação na área do conhecimento em Antropologia, a restituição da fala do outro, suas expressões orais, etc. na modalidade dos testemunhos, dos documentos, de dados e das informações reunidas através de fontes escritas (mas não só estas) tem se transformado, progressivamente, numa pressão ético-moral que orientará suas relações com os sujeitos de pesquisa.

Os constrangimentos epistemológicos que cercam as fontes escritas em Antropologia não podem, assim, ser pensados fora do contexto amplo e mundial em que a sua produção do conhecimento circula, nem distante das pressões das intimações sociais e psicológicas nas quais se origina todo o pensamento humano (afinal, cotidianamente, nós, antropólogos, atuando em nosso campo disciplinar, sofremos os mesmos limites que qualquer outro profissional).

Interessante observarmos que para algumas destas sociedades e povos os dados e informações veiculados pelos etnógrafos passam, através dos fios do tempo, a serem tomadas como "verdadeiro" passado, ao lhe permitir renascer em plena contemporaneidade.

Ao longo de todo o processo, a fonte escrita mantém-se como padecendo de limites em sua pretensão de restituir a fala do outro tanto quanto devolver os dados e documentos recolhidos de sua cultura. Entretanto, há quem se posicione contra este compromisso da escrita com a palavra do outro por reivindicar que a sua devolução acabaria por congelar os povos e as sociedades nas representações etnográficas da época de seu encontro com o etnógrafo (chega-se ao limite do cinismo em afirmar que o compromisso com a restituição da fala do outro acabaria por fechar o outro em sua própria cultura!).

\section{O contraponto com outras fontes da representação etnográfica}

Já vimos que a textualização do trabalho de campo ao retirar uma cultura de suas formas expressivas nativas fornece, portanto, alguns enquadres para a investigação do texto 
etnográfico e o processo de formação de suas fontes escritas. Concordando até certo ponto com David Macdougal (1998), na organização textual de seu trabalho de campo o antropólogo dificilmente se sente escrevendo para o outro ou no lugar do outro, mas sobre a cultura do outro.

Na etnografia como texto, os sujeitos da pesquisa nunca são eles próprios uma vez que se trata de tipos, personalidades ou personagens de uma estória/história narrada pelo próprio antropólogo desde o acontecimento documental que os reuniu. Para Macdougal, não sendo portadora dos traços figurativos do outro, do seu mundo e da sua cultura, as fontes escritas parecem ficar devendo algo às outras formas de linguagem adotadas pelos antropólogos para a expressão de seus pensamentos (como o caso do registro em vídeo, do registro sonoro ou fotográfico).

Sem dúvida, o cinema - por conter o som da fala associado diretamente à imagem do outro - mais que a fotografia - por conter, na forma de um instante, o outro e seus atributos culturais e sociais - e mais que o som - a cultura na sua expressão sonoracontempla uma forma de conhecimento mais completa do que a fonte escrita. Esta é parte da tese de Macdougall (1998), com a qual concordamos parcialmente. Trata-se de uma perspectiva interessante por refletir acerca das contribuições do visual (em especial o cinema) para os avanços do campo do conhecimento antropológico, principalmente, no caso de sua proposta de uma antropologia transcultural, de sociedades que não as ocidentais.

Segundo este autor, as formas visuais tencionam os limites e as potencialidades das formas de conhecimento antropológico (que tem nas fontes escritas sua inspiração), ao dar conta da simultaneidade e dispersão da produção cultural de identidades uma vez que a forma visual produzida pelo próprio etnógrafo sobre a cultura do "nativo" retorna como imagem de si para o outro e sua comunidade cultural de origem. Algo que não ocorre, pelo menos desta forma, com a escrita, mas que também produz efeitos sobre a produção textual dos antropólogos, o que é um dos temas de pesquisa no interior do GT Escrita do BIEV.

Para Macdougall (1998:68, tradução livre do texto do autor) o contraste significativo entre a escrita e o visual em antropologia não reside, entretanto, nas suas grandes diferenças ontologias, nem mesmo suas diferença de formas de construção de significado, mas no controle do significado. Interrogamo-nos se é possível pensar as 
diferenças do controle do significado entre ambas as linguagens e seus respectivos suportes sem abordar o tema das diferenças ontológicas de suas formas expressivas (não se trata da diversidade mas da diferença) e, inclusive, contemporaneamente, da intensa solidariedade entre ambas.

Afinal o que a escrita detém de visualidade, ou o que se pode ver do outro através do que o antropólogo escreve/descreve sobre sua cultura? Concordamos com o autor sobre os efeitos da crítica literária no estudo da fonte escrita da representação etnográfica (autor, autoria, autoridade, estilos, etc.) dela, inclusive, resultando produções irrelevantes para os avanços do conhecimento antropológico. Uma das questões deixadas adormecidas até aqui diz respeito ao tema do poder figurativo que a imagem visual contempla e o seu lugar na fonte escrita da representação etnográfica. Seria interessante pensar quais imagens seriam estas e qual seu estatuto na construção da representação do outro e da sua cultura na contemporaneidade onde as diferentes mídias parecem dialogar com mais intensidade que no passado.

O tema dos textos verbais enunciados pelo outro, no interior do encontro etnográfico, e do seu uso posterior nas construções dos argumentos dos antropólogos a respeito do que dizem como dizem e o porquê dizem em contraposição à representação fílmica, fotográfica, sonora ou videográfica construída desde o acontecimento documental é um dos aspectos realçados por Macdougall (1998) para apresentar as particularidades das fontes visuais da representação etnográfica em relação à escrita.

Para nós, precisamente é na ausência da representação análoga ao acontecimento documental propriamente dito aquilo que enriquece as formas escritas de produção do conhecimento antropológico e o que a torna, por outro lado, especial. É esta "ausência" no corpo da letra que torna a representação etnográfica dada na palavra escrita um espaço nobre de reflexão sobre a presença perturbadora e inquietante da subjetividade do etnógrafo na descrição do outro e de sua cultura.

Segundo Macdougall (1998) as fontes escritas da representação etnográfica podem, por singularidade das formas expressivas de sua linguagem, encobrir/esquecer/ignorar os sentidos e os significados dos dados etnográficos através dos quais interpretamos uma cultura. Esta afirmação do autor se apóia no reconhecimento de que o corpo da letra não faz a captura da cultura do outro a partir da visibilidade de suas formas, tal qual ocorre através 
dos olhos da câmera (fotográfica ou videográfica).

Entretanto, não é menos verdade que a analogia entre o dado etnográfico captado como imagem visual e o corpo vivo do dado etnográfico é aparente e refere-se apenas ao curto espaço de tempo do instante do seu registro, nada garantindo que sua matéria se perpetue após o desligamento da câmera. Além disto, sabemos o quanto o realismo aparente da imagem visual, pelo viés da sua "autenticidade", mais do que a fonte escrita da representação etnográfica ajudou a fixar numa sociedade de consumo e do espetáculo, a identidade de comunidades culturais em traços que interessavam mais as culturais ocidentais que as suas sociedades de origem. Fenômeno que é reconhecido por Macdougall (1998), mas não com a mesma ênfase com que tece suas críticas as fontes escritas do pensamento antropológico, e mesmo as fontes visuais oriundas dos registros fotográficos ou sonoros.

Sob este aspecto é interessante o que coloca este autor no que se refere ao "controle" da representação etnográfica no sentido de a fonte visual permitir ao antropólogo obter o retorno de como a audiência interpreta o registro, a seleção e a edição de suas imagens (ainda mais com as atuais câmeras de vídeo digitais e das maquinas fotográficas digitais que permitem que, ao mesmo tempo se está registrando um acontecimento, às pessoas nele envolvidas possam participar da construção de suas próprias imagens).

O caráter até certo ponto anônimo da representação etnográfica do "nativo" para o caso das fontes visuais certamente se perde e isto a diferencia da fonte escrita. Novamente, o presencial da fonte visual pode ser perigoso tanto quanto o anonimato da fonte escrita, por diversos motivos. Sabemos que a representação etnográfica, independente até certo ponto dos suportes pelos quais os antropólogos optam para seus registros de dados de campo, não adota apenas o acontecimento documental como palco de suas interpretações, nem mesmo se resolve no âmbito da dialogicidade ou não do encontro documental entre ambos. O controle que oferecem as fontes visuais não reside apenas na visibilidade que ela permite dos complexos sistemas simbólicos das outras culturas que não a do etnógrafo. O controle das fontes visuais não pode dispensar as relações que se criaram historicamente entre tais complexos, no âmbito de um processo de mundialização.

Não podemos pensar que apenas as fontes escritas da representação etnográfica estejam contaminadas de exotismos, a exigir do etnógrafo rupturas nas formas expressivas 
através das quais o seu pensamento pode atingir o nível da interpretação das culturas. O mal-estar, portanto, não se atém apenas à expressão escrita do conhecimento antropológico, apenas por sua antiguidade em relação às demais. Ele tende a se alastrar cada vez mais, diante da cultura do espetáculo e do consumo da imagem do outro, para outras fontes sob as quais o pensamento antropológico se vale para construir conhecimento.

Neste ponto se inverte o movimento pendular, e talvez seja o momento das reflexões sobre as fontes escritas do pensamento antropológico contribuir para a desestabilização do excesso de realismo que possa ainda existir no estatuto das fontes visuais para a produção do conhecimento do domínio dos saberes e fazeres da Antropologia.

\section{O lugar da fábula e perturbação da letra na expressão da escrita etnográfica}

Parafraseando J. Ranciére (1995: 32-35) qual seria finalmente um ponto de ancoragem para se pensar a inquietação da escrita ao desenhar a figura do corpo da etnografia? Tentaremos encaminhar uma reflexão desde a retomada de algumas passagens específicas das obras dos autores nos quais estamos apoiando nossos argumentos até o momento.

Apontamos o romanesco e a absolutização da subjetividade, seguindo-se o autor, como um das heranças da escrita etnográfica que resumiria, noutros termos, toda uma literatura que trata da presença ou da ausência da subjetividade do antropólogo como fenômeno inerente a produção do pensamento antropológico. A presença do romanesco se revela na estrutura das narrativas etnográficas quando, por exemplo, de forma insistente, a positividade da voz dos personagens e suas palavras vivas são atravessadas pela positividade da fala do etnógrafo a comentar seus ditos e feitos, na tentativa de exacerbada de objetivação da fábula e do seu próprio poder subjetivo de fabulação.

Neste momento, não há como não remeter a afirmação de Michel de Certeau para quem o lugar do outro é, pois duplamente uma "fábula": a título de um corte metafórico (fari, o ato de falar não tem sujeito nomeável) e a título de um objeto a compreender (a

ficção a traduzir em termos de saber). Como afirma o autor um dizer para o dito - ele é rasura do escrito-, e obrigado a estender nele a produção - ele faz escrever.

Vale à pena referir aqui a sua fabula da letra errante, das andanças da letra 
muda/tagarela, do texto transformado em embalagem, órfão, e dos escritos sem nome que andam pelos embrulhos e enrolam a comida do pobre J. Ranciére (1995) para se pensar então o desentendimento como parte integrante da etnografia na forma de produção textual sobre o outro, o "nativo". Segundo o autor, é este corpo da letra e seu texto órfão, subtraído de sua substancialidade, que o torna capaz de falar com aqueles (o "nativo", o “outro", etc.) a quem, segundo a política da escrita no interior da civilização da letra, não compete o discurso, perturbando desta forma sua ordem.

Considerando a crise da representação dentro do contexto de ruptura pós colonial de que fala P. Rabinow (1999: 94), nos perguntamos até onde tem sido pensada a produção do conhecimento antropológico no contexto do impróprio que toda escrita encerra. Até que ponto o pensamento antropológico tem absorvido criticamente a dramática do literário nas produções escritas, com o antropólogo escancarando no trabalho de campo o poder de disjunção que ela cria entre ele e o outro. Até onde exploramos as divisões entre o pai do discurso (o logos vivo) e o corpo da letra (letra morta, muda/tagarela) como procedimento de organização dos significados do texto etnográfico desde a experiência de campo. Finalmente, até onde assumimos a escrita etnográfica na perspectiva do trajeto da letra desincorporada, reconhecendo-se que seu corpo de verdade não se encerra no interior da escrita etnografica, mas remete ao seu corpus tradicional de origem - a palavra viva. Até aonde como antropólogos assumimos a responsabilidade por este trajeto da letra desencarnada a partir da relação entre o leitor e o escritor, sabendo-se que o corpo da letra expõe sem cessar ao antropólogo a sua condição de letra abandonada à procura de um pai, e ainda mais, que todo o processo esta envolto na complexidade de relações dialógicas historicizadas entre o etnógrafo e o outro a partir dos lugares que ocupam em suas sociedades e culturas.

Desde o ponto de vista de J. Ranciére, discutir a convencionalidade das formas de apresentação do "eu" da narração para a construção da autoridade do antropólogo no texto etnográfico e a substancialidade do conteúdo em termos de verdadeiro ou falso ainda assim não apaziguaria o fato de que o literário na textualidade etnográfica (Clifford, 1998:18) contempla esta disjunção na esfera da própria narração como elemento fundamental da construção do pensamento antropológico. Indo mais além, podemos pensar o literário da escrita etnográfica desde a perspectiva do empréstimo do corpo da letra que tem que fazer 
todo antropólogo em suas escritas antes, ao longo e depois do trabalho de campo para que possa subtrair alguma verdade da sua experiência etnográfica com o outro.

Conforme adotamos a perspectiva deste autor sobre as políticas da escrita nos damos conta de que é o fato da escrita "separar o enunciado da voz que o enuncia legitimamente" aquilo faz sua grandeza e pequenez, e que temos já há algum tempo desfeito desta forma de expressão antropológica ao invés de pensar precisamente, na ordem do legitimo, do próprio, da verdade e as condições da partilha do sensível a que ela se refere. Nos termos de J. Clifford (1998:18) a etnografia como texto apontaria o lugar da escrita na crise de consciência da antropologia em relação a seu status liberal no contexto da ordem imperialista. Não se trata de denunciar os usos reducionistas e dicotômicos da escrita etnográfica, nem de estranhar as relações de poder e de conhecimento que a Antropologia sustenta a partir dela, mas de recolocar a crítica dos modos de representação colonial, pós-colonial e intercultural do outro a partir das condições de enunciação do corpo da letra a partir da inquietação que ela carrega.

È neste ponto que se torna interessante pensar as reflexões de J. Ranciére (1995) para pensar a produção do pensamento antropológico contemporâneo e suas pretensões humanistas, para não dizer, algumas vezes, humanitária. Seguindo o autor, a fonte escrita ao invés de cercar o tema da autoria e da autoridade etnográfica como se vem tratando até o momento pelo viés da hermenêutica - a textualização de uma "experiência" como prérequisito para a interpretação - se desloca para ser pensada em sua vulnerabilidade, em termos de sua condição órfã. Isto é o corpus textual separado de sua condição de enunciação (Clifford, 1998: 40), cria uma perturbação cuja forma adotada não consegue apaziguar (construções de textos através de diálogos, pela via de citações, etc.).

A perturbação que a escrita provoca vai além de qualquer estratégia textual seja para nuançar ou evidenciar o fato de que ela resulta da orquestração de seu autor (no sentido da concretização textual da autoridade, mencionado por J. Cliffford, 1998: 58). O espaço textual de uma etnografia resulta da dramaturgia das aventuras e dos imperativos da escrita, ou seja, da relação da letra e do corpo que lhe falta. A escrita não se opõe ao oral, mas à palavra viva por isto, segundo J. Rancière (1995:98) ela estabelece uma relação entre a ordem dos corpos (por exemplo, o da experiência etnográfica de campo) e a ordem das palavras (por exemplo, o da validade de sua própria significação). 
A dramática do testemunho, do logos vivo que cerca a etnografia com base na observação participante em oposição à letra morta e órfã, à procura de um corpo para lhe dar a sua verdade, recoloca a controvérsia entre verdade (experiência de pesquisa) e mentira (sua tradução num corpus textual organizado) e não tem fornecido novas formas para se pensar a autoridade etnográfica. Certamente nos vale o alerta de P. Rabinow (1999: 81) quando alerta para os perigos parasitários da pesquisa com a escrita dos textos etnográficos que é o dela nutrir-se constantemente dos textos dos outros.

Nos dilema da textualidade da etnografia representar o outro, o que se destaca é a importância da interpretação da cultura deste outro que a escrita necessita para obter seu corpo de verdade; em etnografia o literário da escrita nos mostra que o estranhamento da autoridade etnográfica vem do fato de que é o outro e não apenas o antropólogo e a sua comunidade lingüística que tem que dar à letra seu corpo de verdade. E nem sempre a partilha de sentido para o corpo da letra reúne ambos num diálogo possível entre a ordem dos corpos e a ordem das palavras.

Quando o corpo figurado da letra na forma de fatos culturais representados não encontra seu corpo de verdade (aquele ou aqueles que o encarne) nem mesmo uma estratégia textual alternativa (Clifford, 1998: 55) permite à escrita da etnografia encontrar sua fonte de autoridade e a isto refere provavelmente P. Rabinow (1999: 90) em sua afirmação: hoje, pra além do estranhamento e do relativismo, está o pastiche.

Evidente que esta proposta recupera alguns dos comentários que já fizemos no início deste ensaio. A pretensão de compreender, por um lado, a fonte escrita do conhecimento antropológico como lugar do regime democrático e de confronto com as injustiças, desigualdades e exclusões de povos e cultura que não detêm deste legado para se fazer representar diante da "textura da lei" de Estados e governos e, por outro, como letra órfã "cuja legitimidade nenhum pai garante" (Rancière, 1995: 9). Segundo J. Clifford (1998: 20) o desenvolvimento da ciência etnográfica não pode, em ultima analise, ser compreendida em separado de um debate político-epistemológico mais geral sobre a escrita e a representação da alteridade.

A intenção proposital de investigação do GT da escrita tem sido confrontar o tema clássico da função do autor e as discussões da autoridade etnográfica bem como da intertextualidade e da historia das práticas de leitura e da escrita (e nelas o espaço do livro) 
como polêmicas que podem nos instruir sobre o campo ainda mais complexo das fontes escritas do pensamento antropológico e a importância de se pesquisar suas manifestações e possibilidades para o campo das políticas que conformam as narrativas etnográficas.

Entretanto, pensar o espaço livresco na produção da escrita antropológica, lembrando R. Chartier (1996), é refletir sobre a partilha de sentido do corpo da letra reunindo os antropólogos entre si e estes e os "nativos", ou seja, as condições de possibilidade da letra órfã encarnar um corpo de verdade. Este tema foi abordado até certo ponto por P. Rabinow (1999; 92-95) quando o autor se refere as comunidades interpretativas e as relações entre ética e poder para o caso do debate dos fatos sociais desde a perspectiva da situacionalidade da representação etnográfica Apesar de reconhecermos protocolos de leitura que estão na base na produção textual antropológica ${ }^{5}$, em muitos destes escritos quando o texto passa de um nível de circulação doméstica, para o de publicação impressa, inúmeras vezes, a decisão do editor por este ou aquele título, subtítulo, seqüência de imagens, etc. se dá menos em razão do campo acadêmico e mais do lado comercial da obra, no sentido de tornar sua leitura menos "virtuosistica", nos termos de R. Chartier (1996).

No interior das políticas da escrita e das operações textuais inerentes ao campo de produção de conhecimento em Antropologia, encontram-se, portanto, políticas de leitura. Neste sentido, a produção textual dos antropólogos não esta livre de toda e qualquer lógica das produções culturais, mesmo que não se reduza a ela. O que esta em jogo, por exemplo, no título atribuído por uma editora a uma obra produzida pelo antropólogo? Podem ser as possibilidades de marketing oferecido por seus escritos em função de instigar o leitor potencial, de colocá-lo a par do texto que o espera? Vejamos a obra de Marcel Mauss, Essai sur le don, forme et raison de l'échange dans les société primitives, artigo originalmente publicado no Année Sociologique, segunda série, com data de 1923-1924, e o mesmo artigo compondo uma nova edição, publicada anos mais tarde, em 1950, pela Presse Universitaire Française (PUF) com o título Sociologie e Anthropologie, com o prefácio de C. Lévi-

\footnotetext{
${ }^{5}$ Textos construídos a partir de longos parágrafos, destinado a um público mais selecionado e erudito que textos compostos de parágrafos pequenos, mais descontínuos; a simbologia do grafismo (signos abertos e fechados como pontos de interrogação, de exclamação, de suspensão; signos lógicos como vírgulas, dois pontos, ponto-e-vírgula; signos de marcas seqüenciais, como parênteses, aspas, etc.) traduzem uma maneira de ler a produção textual antropológica no interior de uma tradição livresca fundamental para a construção do seu público-leitor.
} 
Strauss. Uma introdução que fará com que nunca mais a obra de Marcel Mauss possa ser lida ingenuamente, pois influenciou, e continuará influenciando, as formas de ler a obra de M. Mauss por toda uma geração de antropólogos.

Obviamente que como bem coloca P. Rabinow (1999), isto ocorre não somente fora dos muros da academia; podemos pensar uma política de interpretação que abarcaria igualmente o mundo acadêmico em razão das mudanças das relações históricas que reúnem o antropólogo aos seus sujeitos de pesquisa. Uma política da interpretação que abarca igualmente, além das micropráticas da acadêmia, o conjunto dos condicionamentos editoriais que atuam no processo produção do texto etnográfico, pois dele depende as formas particulares nas quais o leitor, erudito ou não, é posto diante "do olhar, da leitura e da audição" da produção de conhecimento antropológica e onde estão em jogo "as competências, convenções, códigos próprios à comunidade a qual pertence cada leitor" (Chartier 1999: 19).

\section{A produção escriturística e a reprodução escrituraria}

O que se encontra fora escrita etnográfica e de suas operações textuais e que precisa por ela ser acessado, ou aludido, ou capturado, ou revelado, ou re-presentificado para que a letra morta possa sair de seu mutismo e torna-se, enfim, falante através de seu corpo reencarnado? O que se torna necessário nas políticas da escrita antropológica para que o corpo da letra descubra seu corpo de verdade? A produção textual dos antropólogos pelo próprio da escrita está endereçada a uma palavra ausente, tanto a minha quanto a do outro, e para ela fazer sentido não adianta o antropólogo aderir a um processo textual desregrado tanto quanto abominá-lo uma vez que o problema do advento da sua legitimidade depende do corpo que atribui sentido a ela (a letra).

Ao mesmo tempo em que estudamos textos clássicos de outros antropólogos nós os produzimos cotidianamente em nossa prática profissional que se quer sempre comprometida com outros corpos e outras palavras que não aqueles de nossos antepassados. Portanto, não há forma das operações textuais da etnografia romperem os significados culturais dos fatos sociais em prol de novas interpretações sem aderir a certo tipo outro de comum do sentido para o corpo da letra ou negar a situação onde emerge seu corpo de verdade. 
Esta aí a inquietação que o corpo da letra gera (a realização do sentido do texto em verdade do corpo, conforme J. Rancière, Políticas da Escrita, 1995: 9), sendo por isto que a textualidade da etnográfica é necessária a prática da produção de conhecimento antropológico, insubstituível na sua singularidade, como qualquer outra forma de expressão do pensamento antropológico (vídeo, filme, fotografia, áudio).

Conforme afirma Michel de Certeau, em termos da etno-grafia e o mundo dos livros, na reprodução escriturária, as diferenças entre "eles" e "nós" revela uma relação de poder nos une. Através dela afirmam-se verdades absolutas e não-perecíveis ainda que tão logo tenham sido enunciadas elas se diluam no tempo. O mesmo já não ocorre com a produção escriturística que se nutre das diferenças entre "nós" e "nós mesmos" (as tribos dos antropólogos), e entre eu e o "mim mesmo", pois é através desta produção que o etnógrafo se relaciona com meus antepassados, isto é, através dos vestígios deixados por eles nas folhas de papel, posteriormente consumido na forma de um livro, e impresso por uma cada editorial qualquer.

Num e noutro caso, permanece tudo aquilo ao que a letra órfã, ao mesmo tempo muda e tagarela, consegue aludir, ao ser lida. Na leitura, o sentido do texto encarnada seu corpo de verdade, revelando o lugar desde onde foi escrita. $\mathrm{O}$ texto etnográfico figura (atesta e materializa) assim tudo aquilo que foi permitido a quem o escreveu ver e que na letra se inscreve; este "tudo" figurando os seus olhos, os seus ouvidos e o seu corpo diante das palavras pronunciadas pelo outro, dos gestos realizados e das ações executadas por ele para o "mesmo".

Sem dúvida, gostaríamos de ressaltar o que Michel de Certeau comenta, J. Rancière retoma e P. Ricoeur desenvolve, ou seja, de que é no ato da escrita que o buraco do tempo se revela, pois é no corpo nu da letra morta, muda e falante, e, acima de tudo órfã, que se coloca o problema da ausência de sentido do que foi pronunciado. Estamos aqui em pleno tema da memória (a escrita invade o espaço e capitaliza o tempo), pois a produção textual dos antropólogos, em especial a operação de escritos etnográficos, embora aluda às lembranças do outro (ouvidas, vividas observadas durante a observação participante, no trabalho de campo) produz, através da sua leitura, um retorno do antropólogo "de si para si”, ainda que pela mediação do outro. Nesta hermenêutica do outro o perigo é de se cair apenas na etnografia de si - mesmo. 
Quando falamos modernamente na repartição do lá (o mundo do outro) e do aqui (o mundo do antropólogo), na separação do que esta fora e o que se situa dentro do texto etnográfico, na dessemelhança do outro e do mesmo que esta na base da produção de conhecimento em Antropologia; a tarefa escriturística do antropólogo parece algo fácil de ser realizado. Entretanto, no momento em que a letra muda se torna falante para o próprio antropólogo-autor é que estas diferenças estruturais no espaço da escrita, com o desenrolar da própria narrativa etnográfica, começam a se embaralham, revelando-lhe uma espessura inaudita para a produção do pensamento antropológico.

Ao escrevermos nossas etno-grafias nós nos damos conta de que a textualidade da cultura supera o próprio registro das idéias do etnógrafo, através dos signos gráficos, numa folha de papel. O olhar "científico" do mundo constrói uma representação para ele e este olhar figura imagens do outro e construídas por mim, etnógrafo. Não há, neste momento, como não se inquietar diante do abismo que nos separa. É preciso que se diga que precisamos contar com o movimento do pensamento, seu desdobramento no tempo, como fenômeno capaz de produzir uma alteração no interior das operações textuais da etnografia. A perturbação que provoca a escrita na procura de seu corpo de verdade permite o deslocamento do si - mesmo do antropólogo diante da palavra viva do outro, este outro que se representa como condição de existência de seu próprio conhecimento. Antes de tentar acomodar a perturbação que o corpo da letra revela para a fonte escrita do pensamento antropológico, podemos pensar com Michel de Certeau (2002), que a escrita etno-gráfica funciona precisamente por que através dela o etnógrafo mantém intacta, diante do outro, a distancia entre eles e o caráter situacional de sua enunciação.

\section{Referências}

BARTHES, R. 2001. «L'Auteur comme absence». In : Brunn, A. (org). L'Auteur, anthologie. Paris : GF-Corpus, texte XXXIII, p. 152-157.

CAPRANZANO, V. 1986. "Hermes dilemma: the masking of subversion in ethnographic description". In: J. Clifford, J \& Marcus, G. (Org.). Writing Cultures: the Poetics and Politics of ethnographic. Berkeley: University of California Press, p. 51-76.

CARDOSO DE OLIVEIRA, R. 2000. O trabalho do antropólogo, Brasília, Paralelo 15, São Paulo, Editora UNESP.

CHARTIER, R.. 1996. Práticas de leitura, São Paulo, Estação liberdade. 1996.

. 1996a. Culture ecrite et société, Paris,Albin Michel. 
UNESP.

1999. A aventura do livro, do leitor ao navegador, São Paulo,

CLIFFORD, J. 1983. "On the authority ethnographic". Representations, vol. I, nº 2, p. 117-146.

DA MATTA, R. 1981. Relativizando. Petrópolis, Vozes.

De CERTEAU, M. 2002. A escrita da Historia, Rio de Janeiro: Forense Universitária. DURAND, G. 1979. Sciencie de l'homme et Tradition, Paris, Berg. International.

EVANS-PRITCHARD, E.E. 1999. Os Nuer,. São Paulo, Perspectiva.

de Janeiro, Jorge Zahar Editores. . 2005. Azande, bruxaria, oráculos e feitiçaria, Rio

FOUCAULT, M. 1966. Les mots et les choses, Paris, Plon. . 2001. «Qu'est-ce qu'un auteur?» In : Brunn, A. (Org). L'Auteur, anthologie. Paris, GF-Corpus, texte VI, p.76-82a. (publicado originalmente em 1969.) GEERTZ, Clifford. 1980. Blurred genres. American Scholar 49: p. 165-170.

1991. Negara, o Estado teatro no século XIX, Lisboa, DIFEL.

Editores. 2001. Nova luz sobre a Antropologia. Rio de Janeiro, Jorge Zahar

Editoria UFRJ. , LEITE, I. B. (org) 2005. Laudos periciais antropológicos em debate, Florianópolis, Coedição NUR/ABA.

LÉVI-STRAUSS C. 1979. Antropologia Estrutural, São Paulo,Tempo Brasileiro.

Vozes. 1982. As estruturas elementares do parentesco, Petrópolis,

MALINOWISKI, B. 1989. Les argonautes du Pacifique occidental, Paris, Gallimard. MARCUS, George E. \& Cushman, Dirck. 1982. «Ethnographies as text”. Annual Review of Anthropology, v. 11, p. 25-69.

MEAD, M. \& BATESON, G. 1962. Balinese's Characters, New York, New York Academy of Sciences.

RABINOW, P. 1986. "Representation are social facts. Modernity and postmodernity in Anthropology.” In: J. Clifford, J \& Marcus, G. (Org.). Writing Cultures: the Poetics and Politics of ethnographic. Berkeley: University of California Press, pp. 234-261.

RANCIÈRE, Jacques. 1996. O desentendimento, São Paulo, Editora 34. 1995. Políticas da Escrita, São Paulo, Editora 34.

SAHLINS, Marshall. 1994. Ilhas de Historia, Rio de Janeiro, Jorge Zahar Editores. 2005. Como pensam os nativos, São Paulo, EDUSP.

SIMMEL, Georg. 1935. Cultura femenina y otros ensayos. Madrid, Revista de Occidente. TAUSSING, M. T. 1980. The devil and commodity fetishism in south America. Chapel Hill: University North Carolina Press. 